\title{
ANALISIS KINERJA KEUANGAN PT PP PRESISI TBK SEBELUM DAN SESUDAH INITIAL PUBLIC OFFERING (IPO)
}

\section{Tiara Khansa' Nabilah}

Politeknik Keuangan Negara STAN

E-mail : tiarakansa@gmail.com

\section{INFORMASI ARTIKEL}

File Diterima:

[01 November 201]

Revisi:

[10 November 2021]

\section{Diterima:}

[1 Desember 2021]

Kata Kunci:

Initial Public Offering (IPO), Rasio Likuiditas, Rasio Solvabilitas, Rasio Aktivitas, Rasio Profitabilitas

\section{ABSTRAK}

This research aims to analyze financial performance of $P T$ PP Presisi Tbk before and after Initial Public Offering (IPO) at the Indonesia Stock Exchange (BEI). This study uses a quantitative approach with statistical method. The result of this research indicates that the corporation action in form of the Initial Public Offering (IPO,) liquidity ratio during the year was well analyzed in the period before the IPO and after the IPO, the solvability ratio showed better results after the IPO, the activity ratio moves volatile, and profitability ratio decreased.

Penelitian ini bertujuan untuk menganalisis kinerja keuangan PT PP Presisi, Tbk sebelum dan sesudah Initial Public Offering (IPO) di Bursa Efek Indonesia (BEI). Penelitian ini menggunakan pendekatan kuantitatif dengan metode statistik. Hasil penelitian menunjukkan setelah adanya aksi korporasi berupa Initial Public Offering (IPO), rasio likuiditas selama tahun yang dianalisis memiliki likuiditas yang cukup baik pada periode sebelum dilakukannya IPO maupun setelah dilakukannya IPO, rasio solvabilitas menunjukkan hasil yang lebih baik setelah IPO, rasio aktivitas bergerak fluktuatif dan rasio profitabilitas mengalami penurunan. 


\section{PENDAHULUAN}

\subsection{Latar Belakang}

Era bisnis yang semakin pesat tentunya akan selalu diiringi dengan adanya persaingan yang semakin ketat di antara para pelaku bisnis. Banyak perusahaan didirikan untuk memberikan kesejahteraan bagi pemiliknya, tetapi tidak semua perusahaan tersebut mampu bertahan untuk mencapai keberhasilannya. Satu dari sekian aspek yang dijadikan tolak ukur keberhasilan suatu perusahaan adalah kemampuan untuk memperluas jangkauan bisnisnya agar dapat bertahan di tengah masyarakat. Dalam usaha untuk memperluas bisnisnya, sumber pendanaan menjadi satu hal yang sangat penting. Satu langkah yang dapat dilakukan oleh perusahaan agar memperoleh sumber pendanaan yang besar adalah dengan menerbitkan saham yang kemudian melakukan penjualan saham tersebut kepada masyarakat.

PT PP Presisi Tbk adalah perusahaan jasa konstruksi berbasis alat berat terintegrasi terkemuka. PT PP Presisi Tbk juga merupakan anak perusahaan dari PT Pembangunan Perumahan (Persero) Tbk, yang juga salah satu perusahaan dengan status BUMN yang menjalankan usaha pada bidang perencanaan dan konstruksi pembangunan. PT PP Presisi Tbk dengan kode perusahaan PPRE telah melaksanakan IPO pada bulan November 2017, dengan harga Rp450/lembar saham pada Bursa Efek Indonesia (BEI). Akan tetapi, saham perusahaan tersebut mengalami penurunan, hingga menjadi Rp416/lembar saham pada saat penutupan. Penurunan harga saham tersebut terus terjadi hingga tahun 2019 yang mencapai Rp314/lembar saham (Bursa Efek Indonesia, 2019).

Salah satu faktor yang menyebabkan penurunan harga saham ini adalah kondisi kinerja keuangan perusahaan. Oleh karena itu, penelitian ini dilakukan untuk untuk menganalisis perbandingan kinerja keuangan PT PP Presisi Tbk sebelum dan sesudah IPO perusahaan go public di tahun 2017. Hasil penelitian ini diharapkan dapat memberikan informasi tentang kondisi keuangan perusahaan yang dapat dijadikan sebagai acuan keputusan dalam berinvestasi saham pada perusahaan objek.

\section{KERANGKA TEORI}

\subsection{Konsep Kekayaan Negara Dipisahkan}

Kekayaan Negara Dipisahkan (KND), menurut Peraturan Menteri Keuangan Nomor 246/PMK.06/2016 tentang Penatausahaan Kekayaan Negara Dipisahkan didefinisikan sebagai Kekayaan negara yang berasal dari Anggaran
Pendapatan dan Belanja Negara dan/atau sumber lainnya dan yang diinvestasikan secara jangka panjang dan berkelanjutan oleh pemerintah pusat serta dikelola secara terpisah dari mekanisme Anggaran Pendapatan dan Belanja Negara.

Kekayaan negara tersebut diinvestasikan dalam bentuk investasi surat berharga atau investasi langsung dalam suatu perusahaan yang dimaksudkan untuk mendapatkan manfaat baik manfaat ekonomi, sosial, maupun manfaat lainnya. Pengelolaan kekayaan negara dipisahkan dilakukan oleh Direktorat Kekayaan Negara Dipisahkan (Dit. KND) yang berada di bawah Direktorat Jenderal Kekayaan Negara (DJKN), Kementerian Keuangan.

\subsection{Konsep Badan Usaha Milik Negara}

Undang - Undang Nomor 19 Tahun 2003 tentang Badan Usaha Milik Negara (BUMN) mendefinisikan BUMN sebagai perusahaan yang sebagian besar modalnya dimiliki oleh negara melalui penyertaan secara langsung yang berasal dari kekayaan negara yang dipisahkan.

Sesuai dengan UU Nomor 19 Tahun 2003 tentang BUMN maksud dan tujuan pendirian BUMN adalah untuk (a) memberikan sumbangan bagi perkembangan perekonomian nasional pada umumnya dan penerimaan negara pada khususnya; (b) mengejar keuntungan; (c) menyelenggarakan kemanfaatan umum berupa penyediaan barang dan/atau jasa yang bermutu tinggi dan memadai bagi pemenuhan hajat hidup orang banyak; (d) menjadi perintis kegiatan - kegiatan usaha yang belum dapat dilaksanakan oleh sektor swasta dan koperasi; (e) turut aktif memberikan bimbingan dan bantuan kepada pengusaha golongan ekonomi lemah, koperasi, dan masyarakat.

\subsection{Konsep Initial Public Offering}

Menurut Ali dan Hartono dalam Afriyani dkk (2020) Initial Public offering (IPO) merupakan kegiatan penawaran saham dari sebuah perusahaan yang dilakukan secara perdana kepada masyarakat (publik) di pasar modal atau bursa. Tujuan dari perusahaan untuk melakukan IPO adalah (a) Strategic Listing; (b)Fund Raising; (c) Public Company.

Hartono (2017) memaparkan keuntungan dari perusahaan yang telah melakukan penawaran saham kepada masyarakat sehingga menjadi perusahaan dengan status going public adalah:

a. Kemudahan untuk meningkatkan modal perusahaan pada masa mendatang. Kebanyakan calon penanam modal enggan 
untuk menanamkan modalnya pada perusahaan yang belum go public, hal ini dikarenakan rendahnya transparansi informasi keuangan dari pihak internal perusahaan kepada penanam modal. Sedangkan pada perusahaan yang sudah go public pihak internal perusahaan memiliki kewajiban untuk melaporkan informasi keuangan kepada masyarakat luas secara berkala di mana kelayakannya telah diperiksa oleh akuntan publik sehingga semua pihak dapat mengakses laporan keuangan tersebut.

a. Bagi perusahaan yang berstatus tertutup dan belum memiliki pasar saham, pemegang saham cenderung mengalami kesulitan dalam menjual sahamnya dibandingkan dengan perusahaan yang telah berstatus go public. Sehingga dengan adanya IPO dapat meningkatkan likuiditas bagi pemegang saham.

b. Pada beberapa alasan, nilai perusahaan penting untuk diketahui. Sebagai contohnya ketika perusahaan hendak memberikan opsi saham (stock option) kepada pihak eksternal perusahaan, maka diperlukan nilai sebenarnya dari opsi saham tersebut. Apabila perusahaan masih berstatus tertutup maka nilai dari opsi saham tersebut tidak dapat dengan mudah ditentukan

\subsection{Analisis Kinerja Keuangan}

Kinerja keuangan adalah analisis yang digunakan untuk mengetahui sampai seberapa jauh perusahaan telah menerapkan aturan - aturan pelaksanaan keuangan secara baik dan benar (Fahmi, 2011). Kinerja keuangan secara langsung akan memberikan gambaran mengenai kondisi keuangan perusahaan yang dianalisis menggunakan alat analisis keuangan, sehingga dapat diketahui bagaimana kondisi keuangan dalam suatu periode tertentu.

Tujuan dari analisis kinerja keuangan perusahaan (Munawir, 2010) adalah :

a. Mengukur tingkat likuiditas, yang menunjukkan kemampuan perusahaan dalam rangka memenuhi kewajiban jangka pendek perusahaan yang akan jatuh tempo.

b. Mengukur tingkat solvabilitas, yang menunjukkan kemampuan perusahaan dalam rangka melunasi seluruh kewajiban perusahaan apabila perusahaan dilikuidasi. Tingkat solvabilitas juga mengindikasikan apakah arus kas perusahaan cukup untuk melunasi seluruh kewajiban perusahaan. c. Mengukur tingkat profitabilitas, yang menunjukkan kemampuan perusahaan dalam memperoleh keuntungan selama satu periode.

d. Mengukur tingkat stabilitas, yang menunjukkan kemampuan perusahaan dalam menjalankan kegiatan operasinya dengan stabil yang dilihat dari kemampuan perusahaan dalam melunasi utang - utang dan beban bunga tepat waktu.

Cara yang digunakan untuk melakukan analisis kinerja keuangan adalah dengan membandingkan laporan keuangan perusahaan dari beberapa periode yang kemudian mencari perbedaan di antara keduanya baik dalam jumlah maupun dalam persentase agar acuan kinerja dapat diperoleh sehingga menghasilkan analisis yang objektif. Analisis tersebut dilakukan dengan menggunakan rasio keuangan. Rasio keuangan dilakukan untuk membandingkan angka - angka yang terdapat pada laporan keuangan sehingga menjadi berarti (Kasmir, 2016). Analisis rasio keuangan dilakukan dengan mengamati data - data yang terdapat pada laporan keuangan perusahaan. Komponen dalam data tersebut kemudian diolah dengan saling dibagi untuk menggambarkan informasi yang relevan. Rasio keuangan mengukur kinerja perusahaan dari beberapa sisi, yaitu likuiditas, solvabilitas, aktivitas, dan profitabilitas perusahaan.

Dalam penelitian ini rasio yang digunakan untuk menganalisis kinerja keuangan perusahaan objek adalah :

a. Rasio Likuiditas.

Rasio likuiditas adalah rasio yang digunakan untuk mengukur tingkat likuiditas suatu perusahaan, dengan cara membandingkan semua komponen yang terdapat pada aktiva lancar dengan komponen pada utang lancar (Kasmir, 2016). Jenis rasio likuiditas yang digunakan dalam penelitian ini adalah :

\section{a) Rasio Lancar (Current Ratio)}

Rasio lancar adalah rasio yang digunakan dalam menentukan ukuran terkait kemampuan perusahaan untuk melunasi kewajiban jangka pendek yang akan segera jatuh tempo pada saat ditagih secara keseluruhan (Kasmir 2016).

Current Ratio $=\frac{\text { Aset Lancar }(\text { Current Assets })}{\text { Utang Lancar }(\text { Current Liabilities })}$

b) Rasio Sangat Lancar (Quick Ratio)

Quick ratio adalah rasio yang digunakan oleh perusahaan untuk mengukur kemampuan 
perusahaan dalam memenuhi utang lancar perusahaan dengan aktiva lancarnya tetapi memberikan pengecualian pada nilai persediaan (Kasmir 2016).

Quick Ratio $=\frac{(\text { Aset Lancar }- \text { Persediaan })}{\text { Utang Lancar }} \times 100 \%$

\section{c) Rasio Kas (Cash Ratio)}

Cash ratio adalah alat yang digunakan untuk menghitung berapa jumlah kas perusahaan yang dapat digunakan untuk melunasi utang perusahaan. Ketersediaan kas tersebut ditandai berdasarkan ada atau tidaknya dana kas atau setara kas seperti rekening giro atau tabungan dari bank (Kasmir, 2016).

$$
\text { Cash Ratio }=\frac{\text { Kas dan setara kas }}{\text { Utang Lancar }}
$$

b. Rasio Solvabilitas

Rasio solvabilitas adalah rasio yang digunakan untuk mengukur seberapa banyak aset perusahaan didanai menggunakan utang (Kasmir, 2016). Jenis rasio Solvabilitas yang digunakan dalam penelitian ini adalah :

a) Rasio utang terhadap aset (Debt to asset ratio)

Debt to asset ratio adalah rasio yang digunakan untuk menghitung perbandingan antara total utang dengan total aset perusahaan. Berapa besaran aset perusahaan yang dibiayai oleh utang atau seberapa besar utang berpengaruh terhadap pengelolaan aset (Kasmir, 2016).

Debt to Total Asset Ratio $=\frac{\text { Total Hutang }}{\text { Total Aktiva }}$

b) Rasio utang terhadap ekuitas (Debt to equity ratio)

Rasio ini digunakan untuk menilai utang dan ekuitas (Kasmir, 2016). Rasio ini berguna untuk mengetahui jumlah dana yang disediakan peminjam (kreditur) dengan pemilik perusahaan atau untuk mengetahui setiap rupiah modal sendiri yang dijadikan jaminan utang.

Debt to Equity Ratio $=\frac{\text { Total Hutang }}{\text { Total Ekuitas }}$

\section{c. Rasio Aktivitas}

Rasio aktivitas adalah rasio yang digunakan untuk mengukur tingkat efisiensi pemanfaatan sumber daya perusahaan seperti penjualan, persediaan, penagihan piutang, dan lainnya (Kasmir, 2016). Dari hasil perhitungan dengan rasio ini akan terlihat apakah perusahaan lebih efisien dalam mengelola aset yang dimiliki atau justru berada pada kondisi yang tidak efisien. Jenis rasio Aktivitas yang digunakan dalam penelitian ini adalah :

\section{a) Perputaran Total Aset (Total Asset Turnover)}

Total asset turnover adalah rasio yang mengukur efisiensi perusahaan dalam mengoptimalkan penggunaan aset perusahaan untuk menghasilkan penjualan (Kasmir, 2016).

Total Asset Turnover $=\frac{\text { Penjualan Bersih }}{\text { Total Aktiva }} \times 1 \mathrm{kali}$

b) Perputaran Aset Tetap (Fixed Asset Turnover)

Manfaat menghitung fixed asset turnover adalah mengetahui berapa kali dana yang ditanamkan pada aset tetap berputar selama kurun waktu tertentu serta menggambarkan seberapa efektif penggunaan aktiva tetap perusahaan untuk melakukan kegiatan bisnis perusahaan (Kasmir, 2016).

Fixed Asset Turnover $=\frac{\text { Penjualan Bersih }}{\text { Total Aktiva Tetap }} \times 1$ kali

d. Rasio Pofitabilitas

Rasio profitabilitas adalah rasio yang digunakan untuk menilai kemampuan perusahaan dalam mencari keuntungan selama periode tertentu. Hasil pengukuran profitabilitas dapat dijadikan alat evaluasi kinerja manajemen apakah manajemen telah bekerja secara efektif atau tidak (Kasmir, 2016). Jenis rasio Profitabilitas yang digunakan dalam penelitian ini adalah :

a) Return on Equity

Return on equity adalah rasio yang menunjukkan sampai seberapa jauh perusahaan mampu untuk mengelola modal sendiri (net worth) secara efektif, mengukur tingkat keuntungan dari investasi yang telah dilakukan pemilik modal sendiri atau pemegang saham perusahaan (Sawir, 2009).

Return on Equity $=\frac{\text { Laba Bersih Setelah Pajak }}{\text { Modal Sendiri }}$

\section{b) Return on Asset}

Return on asset menilai sampai seberapa jauh investasi yang telah ditanamkan mampu memberikan tingkat pengembalian keuntungan sesuai harapan (Fahmi, 2011). Rasio ini digunakan untuk mengukur 
ANALISIS PERBANDINGAN KINERJA KEUANGAN PT PP PRESISI TBK SEBELUM DAN SESUDAH INITIAL PUBLIC OFFERING (IPO).

Tiara Khansa' Nabilah

kemampuan perusahaan dalam mencatatkan keuntungan menggunakan seluruh aset yang dimiliki.

$$
\text { Return on Assets }=\frac{\text { Laba Bersih }}{\text { Total Asset }}
$$

\section{c) Gross Profit Margin}

Rasio ini mengukur efisiensi pengendalian harga pokok atau biaya produksi, yang memberikan indikasi terkait kemampuan perusahaan untuk berproduksi secara efisien (Sawir, 2009).

Gross Profit Margin $=\frac{\text { Penjualan }- \text { Harga Pokok Penjualan }}{\text { Penjualan }}$

d) Net Profit Margin

Net profit margin adalah rasio yang menghitung besarnya persentase laba bersih atas penjualan bersih (Kasmir, 2016).

Net Profit Margin $=\frac{\text { Laba Bersih Setelah Pajak }}{\text { Penjualan }}$

\section{METODE PENELITIAN}

Dalam penelitian ini pendekatan yang digunakan adalah ini pendekatan kuantitatif dengan metode statistik. Analisis data yang dilakukan adalah analisis statistik deskriptif dengan metode analisis horizontal dan vertikal terhadap rasio keuangan dengan sumber data data sekunder yang berasal dari laporan keuangan perusahaan yang dirilis pada tahun 2015 sampai dengan tahun 2019 di situs web objek penelitian dan situs web Bursa efek Indonesia (BEI).

Perusahaan yang menjadi objek dalam penelitian ini adalah PT PP Presisi Tbk yang merupakan perusahaan jasa konstruksi berbasis alat berat terintegrasi terkemuka. PT PP Presisi Tbk juga merupakan anak perusahaan dari PT Pembangunan Perumahan (Persero) Tbk, yang juga salah satu perusahaan dengan status BUMN yang menjalankan usaha pada bidang perencanaan dan konstruksi pembangunan.

\section{HASIL PENELITIAN}

4.1. Kinerja Keuangan Perusahaan Objek

Berdasarkan hasil perhitungan yang telah dilakukan berkaitan dengan kinerja keuangan PT PP Presisi pada periode sebelum dan sesudah perusahaan melakukan penawaran perdana umum saham (IPO) yaitu tahun 2015 hingga tahun 2019, maka didapatkan hasil sebagaimana akan diuraikan berikut ini :

\section{a. Rasio Likuiditas}

Jurnal Indonesia RICH, Vol. 2, No. 2, (2021), 9-16

\section{1) Current Ratio}

Gambar 1.Current ratio Tahun 2015 - 2019

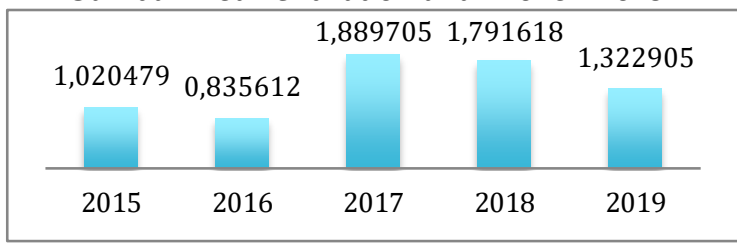

Sumber : Diolah dari Laporan Keuangan Konsolidasian PT PP Presisi Tahun 2015 - 2019

Current ratio perusahaan dari tahun 2015 - 2019 mengalami pergerakan stabil sehingga dikatakan bahwa perusahaan memiliki likuiditas yang cukup baik karena sebagian besar memberikan hasil perhitungan nilai yang lebih dari satu. Namun jika dibandingkan antara dua periode tersebut yaitu sebelum IPO atau tahun 2015 dan 2016 dengan periode setelah IPO atau tahun 2018 dan 2019, maka current ratio perusahaan pada tahun 2018 dan 2019 berada dalam kategori yang lebih baik.

\section{2) Quick Ratio}

Gambar 2. Quick ratio Tahun 2015 - 2019

\begin{tabular}{|ccccc}
\hline \multicolumn{6}{c}{1,8481530} & 1,7461374 & 1,2964475 \\
& & & & \\
\hline 2015 & 2016 & 2017 & 2018 & 2019 \\
\hline
\end{tabular}

Sumber : Diolah dari Laporan Keuangan Konsolidasian PT PP Presisi Tahun 2015 - 2019

Dibandingkan dengan periode sebelum dilakukannya IPO quick ratio perusahaan setelah pelaksanaan IPO menunjukkan hasil yang lebih baik. Pada tahun 2018 dan 2019 perusahaan memiliki kemampuan yang baik untuk melunasi utang lancar perusahaan dengan menggunakan aset lancarnya tanpa mengganggu proses bisnisnya. Hal ini mengindikasikan bahwa kinerja keuangan perusahaan mengalami peningkatan setelah perusahaan melakukan IPO.

\section{3) Cash Ratio}

Gambar 3. Cash ratio Tahun 2015 - 2019

\begin{tabular}{|ccccc}
\hline \multicolumn{5}{c}{0,8041749} \\
0,0863990 & 0,3774790 & 0,3624467 & 0,1599065 \\
\hline 2015 & 2016 & 2017 & 2018 & 2019
\end{tabular}

Sumber : Diolah dari Laporan Keuangan Konsolidasian PT PP Presisi Tahun 2015 - 2019

Baik pada periode sebelum maupun sesudah pelaksanaan IPO, cash ratio perusahaan cenderung memberikan hasil yang rendah, dan tidak terjadi 
perbedaan yang sangat signifikan pada periode setelah IPO, hal ini mengindikasikan bahwa perusahaan harus memiliki kemampuan untuk meningkatakan likuiditas selain dengan pengelolaan utang jangka pendeknya, perusahaan juga harus mampu untuk meningkatkan jumlah kas dan setara kas perusahaan.

\section{b. Rasio Solvabilitas}

\section{1) Debt to Asset Ratio}

Gambar 4. Debt to asset ratio Tahun 2015 2019

\begin{tabular}{|ccccc|}
\hline 0,74995 & 0,80125 & 0,52393 & 0,54655 & 0,59256 \\
& & & & \\
\hline 2015 & 2016 & 2017 & 2018 & 2019 \\
\hline
\end{tabular}

Sumber : Diolah dari Laporan Keuangan Konsolidasian PT PP Presisi Tahun 2015 - 2019

Pergerakan debt to asset ratio perusahaan sepanjang tahun 2015 - 2019 cenderung stabil, tidak terjadi peningkatan atau penurunan yang signifikan. Selama peridoe tersebut debt to asset ratio perusahaan berada pada titik tertingginya pada tahun 2016 dan kemudian kembali menurun di tahun 2017. Debt to asset ratio perusahaan mengalami penurunan di tahun 2017 dan kemudian bergerak stabil sampai dengan tahun 2019, penurunan yang terjadi di tahun 2017 tersebut disebabkan oleh peningkatan aktiva perusahaan yang juga diiringi oleh peningkatan liabilitas perusahaan. Meskipun terjadi penurunan akan tetapi hasil perhitungan masih menunjukkan indikasi nilai lebih dari $50 \%$ yang mana menunjukkan bahwa sebagian aset perusahaan masih dibiayai dengan menggunakan utang.

\section{2) Debt to Equity Ratio}

Gambar 5. Debt to equity Tahun 2015 - 2019

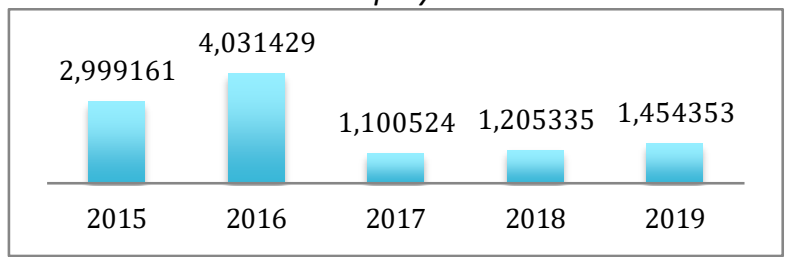

Sumber : Diolah dari Laporan Keuangan Konsolidasian PT PP Presisi Tahun 2015 - 2019

Kondisi perusahaan pada pasca dilakukannya IPO menjukkan kondisi yang lebih baik, hal ini dapat ditunjukkan melalui hasil perhitungan debt to equity ratio perusahaan yang mengalami penurunan karena pada dasarnya semakin kecil hasil dari perhitungan rasio ini menunjukkan bahwa perusahaan memiliki kondisi yang lebih baik, karena semakin sedikit ekuitas milik perusahaan yang dijadikan sebagai jaminan utang perusahaan.

\section{c. Rasio Aktivitas}

\section{1) Total Asset Turnover}

Gambar 6. Total asset turnover Tahun 2015 - 2019

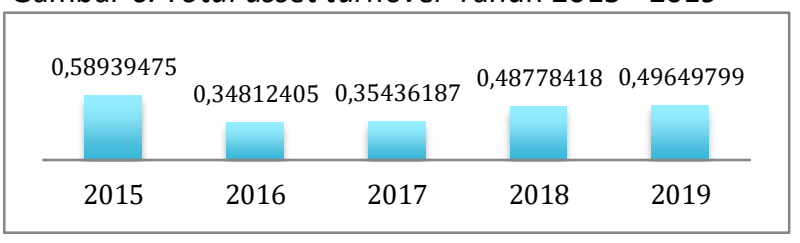

Sumber : Diolah dari Laporan Keuangan

Konsolidasian PT PP Presisi Tahun 2015 - 2019

Perputaran total aset perusahaan berada pada titik tertinggi di tahun 2015 kemudian mengalami penurunan di tahun 2016 dan bergerak stabil hingga kembali mengalami kenaikan di tahun 2018 kemudian kembali bergerak stabil sampai pada tahun 2019. Penurunan total asset turnover perusahaan yang terjadi disebabkan oleh adanya peningkatan jumlah aset yang lebih besar dibandingkan dengan pendapatannya. Sedangkan peningkatan peningkatan aset yang diiringi oleh pendapatannya menyebabkan total asset turnover perusahaan bergerak stabil.

2) Fixed Asset Turnover

Gambar 7. Fixed asset turnover Tahun 2015 - 2019

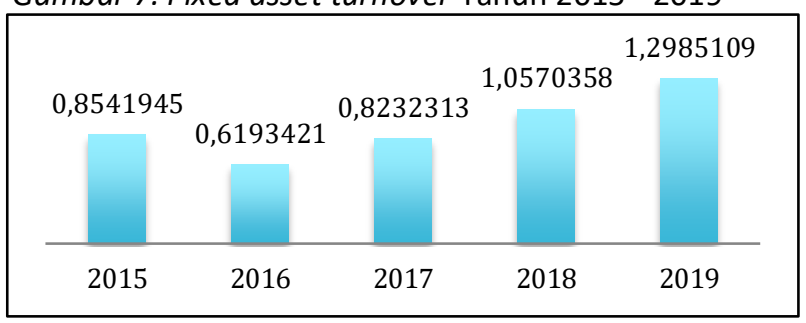

Sumber : Diolah dari Laporan Keuangan

Konsolidasian PT PP Presisi Tahun 2015 - 2019

Fixed asset turnover perusahaan pada periode setelah IPO mengalami peningkatan yang mana menunjukkan bahwa kondisi perusahaan yang semakin baik hal ini sejalan dengan semakin besar hasil perhitungan menunjukkan penggunaan aset tetap yang makin optimal untuk proses bisnis perusahaan.

\section{d. Rasio Profitabilitas}

\section{1) Return On Equity}

Gambar 8. Return on equity Tahun 2015 - 2019 


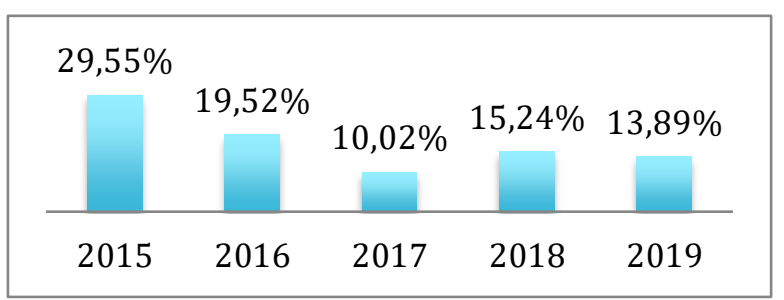

Sumber : Diolah dari Laporan Keuangan Konsolidasian PT PP Presisi Tahun 2015 - 2019

Kondisi perusahaan yang berkenaan dengan kegiatannya untuk mengelola modal dan ekuitas untuk menjalani proses bisnisnya pada saat sebelum IPO lebih baik jika dibandingkan setelah perusahaan melakukan IPO karena hasil perhitungan pada periode sebelum IPO yang lebih besar hal ini sejalan dengan semakin baiknya perusahaan dalam mengelola modal dan ekuitas yang diterimanya untuk menjalankan proses bisnis.

2) Return On Asset

Gambar 9. Return on assetTahun 2015 - 2019

\begin{tabular}{|ccccc|}
\hline $7,39 \%$ & & & $6,91 \%$ & $5,66 \%$ \\
& $3,88 \%$ & $4,77 \%$ & & \\
& & & & \\
\hline 2015 & 2016 & 2017 & 2018 & 2019 \\
\hline
\end{tabular}

Sumber : Diolah dari Laporan Keuangan Konsolidasian PT PP Presisi Tahun 2015 - 2019

Return on asset perusahaan baik sebelum perusahaan melakukan aksi korporasi berupa IPO maupun setelah perusahaan melakukan IPO menunjukkan kondisi yang sama, karena perbedaan antara kedua periode tersebut tidak begitu signifikan. Pada saat setelah IPO perusahaan telah mampu menunjukkan tingkat efektivitas pemanfaatan aset yang makin baik dalam menghasilkan laba. Perusahaan dikatakan telah menggunakan asetnya secara optimal sehingga mendorong peningkatan laba perusahaan. Akan tetapi, angka tersebut mengalami penurunan yang menandakan adanya penurunan efektivitas.

3) Gross Profit Margin

Gambar 10. Gross profit margin Tahun 2015 - 2019

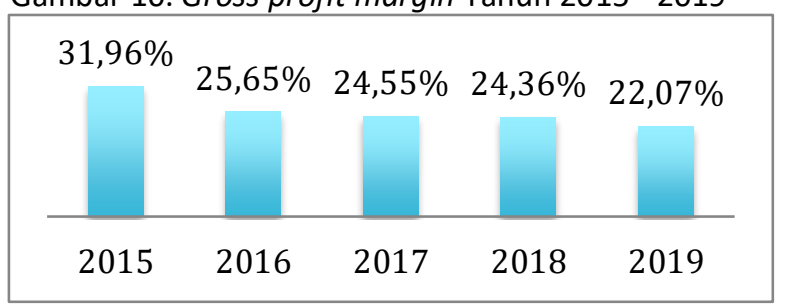

Sumber : Diolah dari Laporan Keuangan

Konsolidasian PT PP Presisi Tahun 2015 - 2019

Sepanjang tahun 2015 sampai dengan 2019 gross profit margin perusahaan bergerak menurun tetapi kondisi ini masih stabil karena penurunan tersebut tidak signifikan. Tahun 2015 merupakan titik tertinggi gross profit margin perusahaan, kemudian di tahun 2016 mengalami penurunan yang disebabkan oleh adanya peningkatan penjualan yang diiringi juga oleh peningkatan harga pokok penjualan perusahaan. Oleh karena itu, baik sebelum perusahaan melakukan aksi korporasi berupa IPO maupun setelahnya tidak terlihat adanya perbedaan yang signifikan pada perusahaan, karena perusahaan tetap mampu untuk menjalankan operasinya dengan baik.

\section{4) Net Profit Margin}

Gambar 11. Net profit margin Tahun 2015 2019

\begin{tabular}{|ccccc|}
\hline $12,5 \%$ & $11,1 \%$ & $13,5 \%$ & $14,2 \%$ & $11,4 \%$ \\
& & & & \\
\hline 2015 & 2016 & 2017 & 2018 & 2019 \\
\hline
\end{tabular}

Sumber : Diolah dari Laporan Keuangan

Konsolidasian PT PP Presisi Tahun 2015 - 2019

Pergerakan net profit margin perusahaan cenderung fluktuatif, pergerakan ini bergantung pada laba yang dibukukan oleh perusahaan dan penjualan yang dilakukan oleh perusahaan. Penurunan net proft margin perusahaan disebabkan adanya peningkatan pendapatan perusahaan yang cukup signifikan yang tidak diimbangi dengan peningkatan signifikan pada laba yang dibukukan perusahaan. Sedangkan peningkatan net profit margin perusahaan terjadi karena adanya peningkatan laba perusahaan yang lebih besar dibandingkan dengan penjualan yang dilakukan oleh perusahaan.

\section{KESIMPULAN DAN SARAN}

\subsection{Kesimpulan}

Dari hasil penelitian dan pembahasan di atas, dapat dikemukakan simpulan sebagai berikut :

1. Rasio likuiditas PT PP Presisi selama tahun yang dianalisis memiliki likuiditas yang cukup baik, baik sebelum dilakukannya IPO maupun setelah dilakukannya IPO. Hal tersebut ditunjukkan dari hasil pengukuran current ratio, quick ratio, serta cash ratio. 
2. Dari hasil perhitungan debt to equity ratio dan debt to asset ratio maka disimpulkan bahwa rasio solvabilitas PT PP Presisi selama tahun analisis menunjukkan pergerakan yang cukup rendah dengan risiko default yang tinggi hal ini dikarenakan sebagian besar aset diperoleh melalui utang dan nilai utang perusahaan selalu lebih tinggi dibandingkan dengan nilai ekuitas perusahaan. Secara umum, solvabilitas PT PP Presisi setelah dilakukannya IPO menunjukkan hasil yang lebih baik, meskipun PT PP Presisi masih terlalu bergantung kepada utang untuk membiayai pertumbuhan perusahaan, hal tersebut terlihat dari tingginya debt to equity ratio dan debt to asset ratio perusahaan. Tingginya hasil perhitungan dari kedua rasio ini juga menandakan bahwa ekspansi yang dilakukan oleh PT PP Presisi terlalu cepat.

3. Rasio Aktivitas pada PT PP Presisi selama tahun analisis bergerak fluktuatif, pemanfaatan aset tetap perusahaan telah dilakukan secara efektif akan tetapi, dari sisi pemanfaatan aset secara keseluruhan masih belum efektif. Berdasarkan pengukuran pada rasio aktivitas PT PP Presisi yang diamati dari sisi total asset turnover maka kondisi lebih baik ditunjukkan pada saat sebelum dilakukannya IPO akan tetapi, jika diamati dari fixed asset turnover maka kondisi lebih baik ditunjukkan setelah dilakukannya IPO.

4. Secara umum, Rasio Profitabilitas PT PP Presisi selama tahun analisis cenderung menunjukkan trend yang menurun. Penurunan profitabilitas perusahaan menunjukkan adanya proses operasi yang dilakukan oleh perusahaan dalam rangka menghasilkan laba yang kurang efisien.

\section{DAFTAR PUSTAKA}

Afriyani, Syukri, A. U., \& Masyita. (2020). Analisis perbandingan kinerja keuangan sebelum dan sesudah Initial Public Offering (IPO) Pada PT Jasa Armada Indonesia, Tbk. Jurnal Mirai Management.

Bursa Efek Indonesia. (2019). Composite. Dipetik Desember 23, 2020, dari PT Bursa Efek Indonesia: idx.co.id

Fahmi, I. (2011). Analisa Laporan Keuangan. Bandung: ALFABETA.

Hartono, J. (2017). Teori Portofolio dan Analisis Investasi. Yogyakarta: BPFE.

Kasmir. (2016). Analisis Laporan Keuangan.

Jakarta: Rajawali Pers.

Pemerintah Republik Indonesia. (2003). Undang Undang Republik Indonesia No. 19 Tahun
2003 tentang Badan Usaha Milik Negara. Jakarta: Sekretariat Negara.

Pemerintah Republik Indonesia. (2016). Peraturan Menteri Keuangan No 246/PMK/06/2016 tentang Penatausahaan Kekayaan Negara Dipisahkan. Jakarta: Sekertariat Negara.

Sawir, A. (2009). Analisa Kinerja Keuangan dan Perencanaan Keuangan Perusahaan. Jakarta: PT Gramedia Pustaka Utama.

Sjadzali, M. (2010). Analisis Laporan Keuangan Edisi Keempat. Yogyakarta: Liberty 


\section{ILUSTRASI TABEL}

Ikhtisar Keuangan PT PP Presisi Tahun 2015 - 2019 (dalam rupiah)

\begin{tabular}{|l|c|c|c|c|c|}
\hline & $\mathbf{2 0 1 5}$ & $\mathbf{2 0 1 6}$ & $\mathbf{2 0 1 7}$ & \multicolumn{1}{c|}{$\mathbf{2 0 1 8}$} \\
\hline Aset Lancar & 117.348 .945 .522 & 466.985 .921 .578 & 2.661 .129 .385 .130 & 3.118 .829 .362 .600 & 4.542 .737 .187 .121 \\
\hline Aset Tidak Lancar & 261.196 .827 .337 & 599.403 .531 .618 & 2.464 .457 .919 .704 & 3.137 .166 .831 .027 & 3.218 .126 .222 .299 \\
\hline Total Aset & $\mathbf{3 7 8 . 5 4 5 . 7 7 2 . 8 5 9}$ & $\mathbf{1 . 0 6 6 . 3 8 9 . 4 5 3 . 1 9 6}$ & $\mathbf{5 . 1 2 5 . 5 8 7 . 3 0 4 . 8 3 4}$ & $\mathbf{6 . 2 5 5 . 9 9 6 . 1 9 3 . 6 2 7}$ & $\mathbf{7 . 7 6 0 . 8 6 3 . 4 0 9 . 4 2 0}$ \\
\hline Liabilitas Jangka Pendek & 114.993 .936 .078 & 558.854 .857 .510 & 1.408 .225 .004 .242 & 1.740 .789 .211 .959 & 3.433 .911 .106 .306 \\
\hline $\begin{array}{l}\text { Liabilitas Jangka } \\
\text { Panjang }\end{array}$ & 168.895 .527 .654 & 295.588 .963 .168 & 1.277 .215 .090 .839 & 1.678 .451 .093 .340 & 1.164 .871 .668 .387 \\
\hline Total Liabilitas & $\mathbf{2 8 3 . 8 8 9 . 4 6 3 . 7 3 2}$ & $\mathbf{8 5 4 . 4 4 3 . 8 2 0 . 6 7 8}$ & $\mathbf{2 . 6 8 5 . 4 4 0 . 0 9 5 . 0 8 1}$ & $\mathbf{3 . 4 1 9 . 2 4 0 . 3 0 5 . 2 9 9}$ & $\mathbf{4 . 5 9 8 . 7 8 2 . 7 7 4 . 6 9 3}$ \\
\hline Total ekuitas & $\mathbf{9 4 . 6 5 6 . 3 0 9 . 1 2 8}$ & $\mathbf{2 1 1 . 9 4 5 . 6 3 2 . 5 1 6}$ & $\mathbf{2 . 4 4 0 . 1 4 7 . 2 0 9 . 7 5 3}$ & $\mathbf{2 . 8 3 6 . 7 5 5 . 8 8 8 . 3 2 8}$ & $\mathbf{3 . 1 6 2 . 0 8 0 . 6 3 4 . 7 2 7}$ \\
\hline Pendapatan & $\mathbf{2 2 3 . 1 1 2 . 8 9 0 . 6 4 3}$ & $\mathbf{3 7 1 . 2 3 5 . 8 1 8 . 4 8 1}$ & $\mathbf{1 . 8 1 6 . 3 1 2 . 6 9 6 . 9 7 4}$ & $\mathbf{3 . 0 5 1 . 5 7 6 . 0 0 1 . 0 6 9}$ & $\mathbf{3 . 8 5 3 . 2 5 3 . 1 0 2 . 0 3 7}$ \\
\hline Beban usaha & $\mathbf{1 0 . 0 9 1 . 1 9 0 . 9 5 6}$ & $\mathbf{1 3 . 9 3 8 . 9 0 9 . 7 0 7}$ & $\mathbf{5 7 . 0 2 9 . 6 3 2 . 6 6 9}$ & $\mathbf{8 3 . 0 3 1 . 3 4 9 . 6 3 5}$ & $\mathbf{7 0 . 2 6 8 . 7 9 4 . 4 0 1}$ \\
\hline Laba Bersih & $\mathbf{2 7 . 9 7 5 . 1 0 0 . 7 5 3}$ & $\mathbf{4 1 . 3 6 2 . 8 2 2 . 8 0 3}$ & $\mathbf{2 4 4 . 5 5 0 . 4 6 6 . 3 9 6}$ & $\mathbf{4 3 2 . 2 9 8 . 1 5 7 . 9 8 5}$ & $\mathbf{4 3 9 . 2 5 3 . 2 6 3 . 1 0 8}$ \\
\hline
\end{tabular}

